\title{
Knowledge Translation in the Healthcare Sector. A Structured Literature Review
}

\author{
Francesca Dal Mas ${ }^{1}$, Alexeis Garcia-Perez ${ }^{2}$, Maria José Sousa ${ }^{3}$, Renato Lopes da Costa ${ }^{3}$ and \\ Lorenzo Cobianchi ${ }^{4}$ \\ ${ }^{1}$ Lincoln International Business School, University of Lincoln, Lincoln, UK \\ ${ }^{2}$ Faculty Research Centre for Business in Society, Coventry University, UK \\ ${ }^{3}$ ISCTE - Instituto Universitário de Lisboa, Portugal \\ ${ }^{4}$ Dipartimento di Scienze Clinico-Chirurgiche, Diagnostiche e Pediatriche, Università degli Studi di \\ Pavia, Pavia, Italy; Dipartimento di Scienze Chirurgiche, Fondazione IRCCS Policlinico San Matteo, \\ Pavia, Italy \\ fdalmas@lincoln.ac.uk \\ alexeis.garcia-perez@coventry.ac.uk \\ maria.jose.sousa@iscte-iul.pt \\ renato jorge_costa@iscte-iul.pt \\ lorenzo.cobianchi@unipv.it \\ DOI: 10.34190/EJKM.18.03.001
}

\begin{abstract}
Knowledge translation can be understood as the ability to translate concepts between different contexts by stakeholders who have different skills, aims, and even feelings in their relation to such concepts. Knowledge translation tools allow for the effective transfer of existing knowledge as well as the emergence of new knowledge of value to some or all of the stakeholders involved in the process. Knowledge translation is particularly challenging in healthcare and medicine, where different practitioners (e.g. physicians, biologists, engineers, researchers) and professionals need methodologies and tools to communicate and share knowledge among them and with patients in an effective manner. To better understand this phenomenon, we conducted a Structured Literature Review (SLR). The concepts knowledge, translation and either healthcare or medicine were used as search terms in the title, abstract or keywords on Scopus, which highlighted more than 2,000 contributions in the medical literature and only 22 in Business and Management. Our review of these documents revealed a need in the healthcare sector for better managerial and organisational practices to cope with the various challenges related to the sharing of knowledge among stakeholders. At the same time, the business and management communities appear to have made significant progress in addressing the same issues. We therefore decided to concentrate our analysis on the works published by the business and management community as a mean to highlight future research directions for the healthcare management sector. Thus, our research identifies areas of relevance which are currently underdeveloped, provides insights on both theoretical and empirical developments and offers a critique of the approaches, research frameworks and methods used, as well as emerging trends in these domains. Despite a lack of an agreed definition of the term Knowledge Translation, our findings highlight a growing interest in the topic, with most of the contributions published after 2015. Scholars have approached the term from a variety of perspectives depending on the nature of the stakeholders of relevance to their studies. Whilst there does not seem to be a predominant framework, the literature reveals several tools and techniques that are effective in enhancing Knowledge Translation in different contexts. New research opportunities in this domain emerge in terms of underinvestigated areas within the healthcare sector.
\end{abstract}

Keywords: Knowledge Translation, Healthcare, Knowledge Management, Knowledge Transfer • Medicine

\section{Introduction}

Knowledge management stands as a crucial business process in both the private as well as the public sector(Aureli et al., 2019; Del Giudice and Maggioni, 2014; Massaro, Dumay, and Garlatti, 2015; Sousa, 2010). Among the various fields, healthcare stands as a critical one, given its ability to impact on people's lives and wellbeing (Reay et al., 2017; Ware et al., 2008). The relevance of knowledge and its management in the healthcare scenario has been widely investigated in the literature (Ferlie et al., 2015; Jacquinet et al., 2019; Miller, 2015; Sánchez-Polo et al., 2019; Sousa et al., 2020).

Still, the healthcare sector is currently under great pressure, and several challenges to be addressed have arisen. The impact of new technologies like mixed and augmented reality, artificial intelligence, robotics, big data analytics are affecting several medical disciplines, changing the way surgery, diagnosis, and treatments are performed (Dal Mas, Piccolo and Ruzza, 2020; Dal Mas et al., 2020b; Dal Mas et al., 2019b; Giulianotti et al., 2003; Presch et al., 2020).Innovation involves not only new medical equipment and instruments but also 
clinical protocols, like in the case of oncology (Cobianchi et al., 2016; Hogan et al., 2012; Vitolo et al., 2019). Medical doctors and clinical staff require new skills and training methods (Garcia Vazquez et al., 2020), and blended curricula are leading to new professional figures, like technical physicians (Groenier, Pieters, and Miedema, 2017). Several budget reductions, especially in developed countries (Massaro, Dumay, and Garlatti, 2015) make it difficult to cope with the increasing request for outpatient and inpatient services by an ageing population (Howdon and Rice, 2018) with more chronic diseases (Miceli et al., 2017). The recent COVID-19 pandemic at the beginning of 2020 (WHO, 2020) has furthered highlighted the need, for the entire healthcare system, to profoundly review its global strategies (Cobianchi et al., 2020a, 2020c).

In this evolving international scenario, the healthcare ecosystem had to open up its boundaries to the engagement and the interaction of several different stakeholders (Ardito and Messeni Petruzzelli, 2017; Secundo et al., 2019). Not only multidisciplinary and diverse teams are more and more involved in clinical practices and medical innovation (Cobianchi et al., 2020b; Qadan et al., 2020; Saini et al., 2012), but the patient plays a central role in the co-production of the healthcare products or services (Batalden et al., 2016; Elwyn et al., 2019). In the modern healthcare scenario, patients are more and more engaged in the co-design (Hussain and Sanders, 2012; Reay et al., 2017) and co-production of their needed services (Biancuzzi et al., 2020; Dal Mas et al., 2020a), in a patient-centric perspective (Brunoro-Kadash and Kadash, 2013).

The transfer and sharing of knowledge stand as key tasks to ensure the creation of new knowledge and innovation (Sousa, 2015). Still, the presence of a variety of stakeholders with different characteristics makes it challenging to manage the knowledge flows properly (Sousa et al., 2020). Distinct features in terms of competencies, needs, feelings, education create barriers in the transfer and sharing of knowledge, calling for a translation process to enable knowledge, data, and information to be understood and exchanged successfully.

The topic of knowledge translation is gaining increasing attention both from academia as well as practice due to its crucial role in supporting innovation in various business fields (Lander, 2016). Savory (2006) highlights how the social nature of knowledge needs something more than a "knowledge transfer." A complete translation is necessary, recalling the idea of a foreign language which is translated into another language in a different environment (Simeone, Secundo and Schiuma, 2017, 2018). The translation act recalls metaphorical thinking (Bratianu and Bejinaru, 2019; Lakoff and Johnson, 1999), as part of a mental process to understand and handle new knowledge and information (Pinker, 2007).

While the topic of knowledge translation is considered relevant in several business fields (Bagnoli et al., 2020; Massaro et al., 2019; Simeone et al., 2018), it is even more prevalent in healthcare and medicine. At the time of our analysis, the search key "knowledge AND translation AND healthcare OR medicine" in the title, abstract, or keywords on the scientific database Scopus led more than 3,000 contributions of which over 2,000 in the medical and clinical literature. Still, just a few contributions were labelled under the business and management fields.

Our initial thought was that the topic had been better developed in healthcare than it was in business and management. However, an initial analysis revealed how many of those works published in healthcare had mentioned knowledge translation as a challenge in the context of the research, rather than focusing on it as part of solutions. Additionally, those works from the healthcare sector that were focused on the concept of knowledge translation were reporting research conducted in business and management.

In these circumstances, we concluded that there was more value for the research and practice communities in a review of a smaller number of highly relevant contributions from the business and management domain than a larger, less focused and therefore less productive review of the research in the healthcare sector which, ultimately, would only confirm the need for a review of works published in other contexts.

Moreover, the recent challenges and events which are impacting on the healthcare scenario, including the COVID-19 pandemic, have stressed the need to identify successful managerial practices to redesign the new healthcare system (Lillemoe, 2020). Furthermore, the recent clinical literature connected to the COVID-19 events has suggested the need for a multidisciplinary approach to medicine (Brindle and Gawande, 2020; Cobianchi et al., 2020c; Grasselli, Pesenti, and Cecconi, , 2020; Qadan et al., 2020), in which managerial practices and strategies play a central role (Cobianchi et al., 2020a; Cobianchi et al., 2020c; Parodi and Liu, 2020; Wang, Ng, and Brook, 2020). 
Starting from these premises, this paper aims to investigate the current debate on knowledge translation in healthcare and medicine by conducting a Structured Literature Review (SLR), according to the framework of Massaro, Dumay, and Guthrie (2016). Our first attempt to map the phenomenon, taking into consideration the need to study it from a managerial perspective, includes only the works published in the Business and Management field, meaning in journals or books which are labelled to belong to the Business and Management areas. The aim is to understand the dialogue about the managerial and organisational practices involving organisations belonging to the healthcare sector in the translation of knowledge among the business rather than the clinical community, to spot the most relevant topics, techniques, and research and practical implications. Our preliminary analysis made us understand how exploring the subject in the context of Business and Management (particularly if related to healthcare organzations) would serve to inform the direction of research in the healthcare sector.

\section{Research method}

This paper employs a Structured Literature Review approach (Massaro, Dumay, and Guthrie, 2016). An SLR "can help experienced scholars develop new and interesting research paths by accessing and analysing a considerable volume of scholarly work" (Massaro, Dumay, and Guthrie, 2016). Moreover, it can "contribute to developing research paths and questions by providing a foundation" for future research activities, by providing a different choice to classic literature reviews to lead to more "defensible" and "replicable" outcomes.

The following paragraphs summarise the steps undertaken to conduct the SRL.

\subsection{Write a literature review protocol and define the questions that the literature review is setting out to answer}

A first preliminary protocol was defined to document the procedures followed in undertaking and in developing the literature review, and in making it repeatable and trustworthy. The initial protocol document contributed to identifying three central research questions.

RQ 1: What are the main features of the literature on knowledge translation in healthcare and medicine, seen from a managerial perspective?

RQ 2: What are the most frequent issues and themes/topics of this literature?

RQ 3: What seem to be the possible implications for future research in this field?

\subsection{Determine the type of studies and carry out a comprehensive literature research}

We used the database Scopus to identify relevant contributions to be analysed. At the time of the study, the search key "knowledge AND translation AND healthcare OR medicine" in the title, abstract, or keywords on Scopus led to more than 3,000 total contributions of which over 2,000 in the medical and clinical literature and only 22 in Business and Management. Of those 22 between papers and book chapters, 18 have been considered appropriate for the analysis and thus have been coded using Nvivo.

The following table summarises the selected contributions included in the SLR. One first result comes once browsing the year of publication. While the earliest work is dated back in 2008 , ten contributions $(55 \%$ of the sample) were published after 2015, highlighting the increasing interest towards the topic. 
Table 1: Authors, articles, and sources

\begin{tabular}{|c|c|c|c|}
\hline Authors & Title & $\begin{array}{l}\text { Ye } \\
\text { ar }\end{array}$ & Source title \\
\hline $\begin{array}{l}\text { Karimi, L., Dadich, A., Fulop, } \\
\text { L., Leggat, S.G., Eljiz, K., } \\
\text { Fitzgerald, J.A., Smyth, A., } \\
\text { Hayes, K.J., Kippist, L. }\end{array}$ & $\begin{array}{l}\text { Brilliant health service management: } \\
\text { challenging perceptions and changing HR } \\
\text { practices in health services }\end{array}$ & $\begin{array}{l}20 \\
19\end{array}$ & $\begin{array}{l}\text { Asia Pacific Journal of Human } \\
\text { Resources }\end{array}$ \\
\hline $\begin{array}{l}\text { Fulop, E.L., Kippist, L., } \\
\text { Dadich, A., Hayes, K., } \\
\text { Karimi, L., Symth, A. }\end{array}$ & $\begin{array}{l}\text { What makes a team brilliant? An experiential } \\
\text { exploration of positivity within healthcare }\end{array}$ & $\begin{array}{l}20 \\
19\end{array}$ & $\begin{array}{l}\text { Journal of Management and } \\
\text { Organization }\end{array}$ \\
\hline $\begin{array}{l}\text { Grigoriadis, N., Bakirtzis, C., } \\
\text { Politis, C., Danas, K., } \\
\text { Thuemmler, C., Lim, A.K. }\end{array}$ & $\begin{array}{l}\text { A health } 4.0 \text { based approach towards the } \\
\text { management of multiple sclerosis }\end{array}$ & $\begin{array}{l}20 \\
17\end{array}$ & $\begin{array}{l}\text { Health 4.0: How Virtualization and } \\
\text { Big Data are Revolutionizing } \\
\text { Healthcare }\end{array}$ \\
\hline $\begin{array}{l}\text { Currie, J., Mateer, J., } \\
\text { Weston, D., Anderson, E., } \\
\text { Harding, J. }\end{array}$ & $\begin{array}{l}\text { Implementation of a clinical governance } \\
\text { framework to } 17 \text { Combat Service Support } \\
\text { Brigade, Australian Army }\end{array}$ & $\begin{array}{l}20 \\
17\end{array}$ & $\begin{array}{l}\text { International Journal of Health } \\
\text { Governance }\end{array}$ \\
\hline $\begin{array}{l}\text { Mohaghegh, N., Zarghani, } \\
\text { M., Tahamtan, I., } \\
\text { Ghasghaee, A., Mousavi, S. }\end{array}$ & $\begin{array}{l}\text { Assessing knowledge translation in Iranian } \\
\text { medical research centres }\end{array}$ & $\begin{array}{l}20 \\
17\end{array}$ & $\begin{array}{l}\text { International Journal of } \\
\text { Information Science and } \\
\text { Management }\end{array}$ \\
\hline Dadich, A., Olson, R.E. & $\begin{array}{l}\text { How and why emotions matter in } \\
\text { interprofessional healthcare }\end{array}$ & $\begin{array}{l}20 \\
17 \\
\end{array}$ & \begin{tabular}{|l|} 
International Journal of Work \\
Organisation and Emotion
\end{tabular} \\
\hline $\begin{array}{l}\text { D'Andreta, D., Marabelli, } \\
\text { M., Newell, S., Scarbrough, } \\
\text { H., Swan, J. }\end{array}$ & $\begin{array}{l}\text { Dominant Cognitive Frames and the Innovative } \\
\text { Power of Social Networks }\end{array}$ & $\begin{array}{l}20 \\
16\end{array}$ & Organization Studies \\
\hline Lander, B. & $\begin{array}{l}\text { Boundary-spanning in academic healthcare } \\
\text { organisations }\end{array}$ & $\begin{array}{l}20 \\
16\end{array}$ & Research Policy \\
\hline $\begin{array}{l}\text { Dadich, A., Abbott, P., } \\
\text { Hosseinzadeh, H. }\end{array}$ & $\begin{array}{l}\text { Strategies to promote practice nurse capacity to } \\
\text { deliver evidence-based care: An example from } \\
\text { sexual healthcare }\end{array}$ & $\begin{array}{l}20 \\
15\end{array}$ & $\begin{array}{l}\text { Journal of Health, Organisation } \\
\text { and Management }\end{array}$ \\
\hline Avila-Robinson, A., Islam, N. & $\begin{array}{l}\text { Evolution of emerging iPS cell-based therapies } \\
\text { for age-related macular degeneration (AMD) }\end{array}$ & $\begin{array}{l}20 \\
15\end{array}$ & $\begin{array}{l}\text { Portland International Conference } \\
\text { on Management of Engineering } \\
\text { and Technology }\end{array}$ \\
\hline $\begin{array}{l}\text { Radaelli, G., Lettieri, E., } \\
\text { Mura, M., Spiller, N. }\end{array}$ & $\begin{array}{l}\text { Knowledge sharing and innovative work } \\
\text { behaviour in healthcare: A micro-level } \\
\text { investigation of direct and indirect effects }\end{array}$ & $\begin{array}{l}20 \\
14\end{array}$ & $\begin{array}{l}\text { Creativity and Innovation } \\
\text { Management }\end{array}$ \\
\hline $\begin{array}{l}\text { Oborn, E., Barrett, M., } \\
\text { Racko, G. }\end{array}$ & $\begin{array}{l}\text { Knowledge translation in healthcare: } \\
\text { Incorporating theories of learning and } \\
\text { knowledge from the management literature }\end{array}$ & $\begin{array}{l}20 \\
13\end{array}$ & $\begin{array}{l}\text { Journal of Health Organization and } \\
\text { Management }\end{array}$ \\
\hline $\begin{array}{l}\text { Brunoro-Kadash, C., } \\
\text { Kadash, N. }\end{array}$ & $\begin{array}{l}\text { Time to care: A patient-centered quality } \\
\text { improvement strategy }\end{array}$ & $\begin{array}{l}20 \\
13\end{array}$ & Leadership in Health Services \\
\hline $\begin{array}{l}\text { Baigorri, A., Villadangos, J., } \\
\text { Astrain, J.J., Córdoba, A. }\end{array}$ & $\begin{array}{l}\text { A medical knowledge management system } \\
\text { based on expert tagging (MKMST) }\end{array}$ & $\begin{array}{l}20 \\
13\end{array}$ & $\begin{array}{l}\text { WIT Transactions on Information } \\
\text { and Communication Technologies }\end{array}$ \\
\hline $\begin{array}{l}\text { Komporozos-Athanasiou, } \\
\text { A., Oborn, E., Barrett, M., } \\
\text { Chan, Y.E. }\end{array}$ & $\begin{array}{l}\text { Policy as a struggle for meaning: Disentangling } \\
\text { knowledge translation across international } \\
\text { health contexts }\end{array}$ & $\begin{array}{l}20 \\
11\end{array}$ & $\begin{array}{l}\text { Knowledge Management Research } \\
\text { and Practice }\end{array}$ \\
\hline Ioannidis, J.P.A. & $\begin{array}{l}\text { Limits to forecasting in personalized medicine: } \\
\text { An overview }\end{array}$ & $\begin{array}{l}20 \\
09\end{array}$ & $\begin{array}{l}\text { International Journal of } \\
\text { Forecasting }\end{array}$ \\
\hline Savory, C. & $\begin{array}{l}\text { Building knowledge translation capability into } \\
\text { public-sector innovation processes }\end{array}$ & $\begin{array}{l}20 \\
09\end{array}$ & $\begin{array}{l}\text { Technology Analysis and Strategic } \\
\text { Management }\end{array}$ \\
\hline $\begin{array}{l}\text { Ware, C., Buckwell, C., } \\
\text { Small, S., Wood, R. }\end{array}$ & $\begin{array}{l}\text { Activation of evidence: A new approach to } \\
\text { knowledge translation and closing the clinical } \\
\text { care gap }\end{array}$ & $\begin{array}{l}20 \\
08\end{array}$ & Journal of Medical Marketing \\
\hline
\end{tabular}

\subsection{Define an analytical framework}

A fundamental step in conducting an SLR is the definition of a framework of analysis. The list of the leading nodes and sub-nodes is taken from previous SLR papers, adapted to the aim of the study.

The first category of nodes is about the type of authors, dividing them into scholars vs practitioners. The second category refers to the location where the study is conducted (Massaro, Dumay, Garlatti, 2015). The third category is about the sector type, dividing it into public and private sectors. The fourth group of nodes 
refers to the healthcare sector, while the fifth one is about the healthcare service. The sub-nodes of the fourth and fifth category were added while coding the papers. The sixth category concerns the research methodology used in the study (Dal Mas et al., 2019a; Massaro, Dumay, and Garlatti, 2015). The seventh category analyses the framework model used (Dal Mas al., 2019a; Massaro, Dumay, and Garlatti, 2015; Massaro et al., 2016). The eighth node group maps the type of knowledge translation explained in the research and the eventual definition given. The ninth category analyses the knowledge translation tools cited in the various studies. The tenth category is about the eventual explanation of the findings. The last three categories refer to the eventual research, practical, and policy implications.

The following table summarises the framework model and the main results of the coding.

Table 2: Analytical framework

\begin{tabular}{|c|c|c|c|}
\hline Category & Variables & Results & $\%$ \\
\hline \multirow[t]{3}{*}{ Author type } & Scholars & 15 & $83 \%$ \\
\hline & Practictioners & 1 & $6 \%$ \\
\hline & Practitioners and scholars & 2 & $11 \%$ \\
\hline \multirow[t]{11}{*}{ Location } & Continental Europe & 2 & $11 \%$ \\
\hline & UK & 2 & $11 \%$ \\
\hline & Australia & 5 & $28 \%$ \\
\hline & North America & 2 & $11 \%$ \\
\hline & Central South America & 0 & $0 \%$ \\
\hline & Asia & 1 & $6 \%$ \\
\hline & Africa & 0 & $0 \%$ \\
\hline & New Zealand & 0 & $0 \%$ \\
\hline & Russia & 0 & $0 \%$ \\
\hline & Various countries together & 1 & $6 \%$ \\
\hline & No Location & 5 & $28 \%$ \\
\hline \multirow[t]{4}{*}{ Sector type } & Public Sector & 13 & $72 \%$ \\
\hline & Private Sector & 1 & $6 \%$ \\
\hline & Both private and public sector & 0 & $0 \%$ \\
\hline & General & 4 & $22 \%$ \\
\hline \multirow[t]{9}{*}{ Healthcare Sector } & Scientific and Clinical Research & 3 & $17 \%$ \\
\hline & Hospitals & 4 & $22 \%$ \\
\hline & Army & 1 & $6 \%$ \\
\hline & Government agencies & 5 & $28 \%$ \\
\hline & Interprofessional Practices & 1 & $6 \%$ \\
\hline & E-Health & 1 & $6 \%$ \\
\hline & Academic Healthcare Organizations & 1 & $6 \%$ \\
\hline & General & 1 & $6 \%$ \\
\hline & Pharma & 1 & $6 \%$ \\
\hline \multirow[t]{13}{*}{ Healthcare Service } & Regenerative Medicine & 1 & $6 \%$ \\
\hline & Radiology & 1 & $6 \%$ \\
\hline & Neuroscience & 1 & $6 \%$ \\
\hline & Governamental Army & 1 & $6 \%$ \\
\hline & Governamental Networks & 1 & $6 \%$ \\
\hline & Primary Healthcare & 1 & $6 \%$ \\
\hline & Oncology & 2 & $11 \%$ \\
\hline & Multiple Sclerosis & 1 & $6 \%$ \\
\hline & Personalised Medicine & 1 & $6 \%$ \\
\hline & Quality Healthcare & 1 & $6 \%$ \\
\hline & Stroke & 1 & $6 \%$ \\
\hline & Infection and immunology & 1 & $6 \%$ \\
\hline & General Clinical Research & 1 & $6 \%$ \\
\hline
\end{tabular}




\begin{tabular}{|c|c|c|c|}
\hline Category & Variables & Results & $\%$ \\
\hline & General & 2 & $11 \%$ \\
\hline & Palliative care & 1 & $6 \%$ \\
\hline & Pharma & 1 & $6 \%$ \\
\hline \multirow[t]{8}{*}{ Research Method } & Quantitiave cross-sectional & 3 & $17 \%$ \\
\hline & Case Study & 4 & $22 \%$ \\
\hline & Literature review - normative & 2 & $11 \%$ \\
\hline & Other qualitative & 2 & $11 \%$ \\
\hline & Viewpoint & 2 & $11 \%$ \\
\hline & Mixed methods & 2 & $11 \%$ \\
\hline & Interviews & 2 & $11 \%$ \\
\hline & Discourse Analysis & 1 & $6 \%$ \\
\hline \multirow[t]{3}{*}{ Framework } & No framework-model used & 6 & $33 \%$ \\
\hline & Applies previous framework & 10 & $56 \%$ \\
\hline & Proposes a new framework-model & 2 & $11 \%$ \\
\hline \multirow[t]{3}{*}{ Definition of Knowledge Translation } & Type of KT & 16 & $89 \%$ \\
\hline & No & 0 & $0 \%$ \\
\hline & Clear definition & 6 & $33 \%$ \\
\hline \multirow[t]{2}{*}{ Knowledge Translation tools } & Yes & 18 & $100 \%$ \\
\hline & No & 0 & $0 \%$ \\
\hline \multirow[t]{2}{*}{ Findings } & Explains findings & 15 & $83 \%$ \\
\hline & Not explained & 3 & $17 \%$ \\
\hline \multirow[t]{2}{*}{ Research implications } & Explains research implications & 8 & $44 \%$ \\
\hline & Not explained & 10 & $56 \%$ \\
\hline \multirow[t]{2}{*}{ Practical implications } & Explains practical implications & 13 & $72 \%$ \\
\hline & Not explained & 5 & $28 \%$ \\
\hline \multirow[t]{2}{*}{ Policy implications } & Explains policy implications & 7 & $39 \%$ \\
\hline & Not explained & 11 & $61 \%$ \\
\hline
\end{tabular}

\section{Findings, insights and critique}

This section analyses the coding to answer to RQ1: What are the main features of the literature on knowledge translation in healthcare and medicine, seen from a managerial perspective? and RQ2: What are the most frequent issues and themes/topics of this literature?

\subsection{Author types}

Scholars wrote almost all the papers. Practitioners authored only one article, and just two works are the joint effort of scholars and practitioners together.

\subsection{Location}

Interesting enough, five papers are about Australia. Continental Europe, the UK, and North America account for two studies each. Only one work comes from Asia. Several articles do not refer to any locations. No studies were conducted in Africa or Central/South America.

\subsection{Sector type}

Most papers refer to the public sector. Only one paper is about the private sector.

\subsection{Healthcare Sector}

The most analysed sectors are government agencies (five works), hospitals (four works), and scientific and clinical research (three works). Additional sectors are investigated but only with one article.

\subsection{Healthcare Service}

As can be seen from Table 2, results are incredibly fragmented. Only oncology and healthcare in general terms are present in two papers. 


\subsection{Research Methods}

There does not seem to be a dominant research method used. Authors use quantitative as well as qualitative studies, and there are literature reviews and viewpoints as well.

\subsection{Framework model}

Although six papers do not use or clarify the framework model used, most of the authors declare to use an existing framework. However, all models are different, since there is no framework which is used more than one time.

The key frameworks that are currently used in the literature include, among others: institutional theory (Dadich and Olson, 2017), critical discourse analysis (Komporozos-Athanasiou et al., 2011), mode 2 knowledge production (Savory, 2009), linear translation by Nelson at al. (2011) and Morlacchi and Nelson (Avila-Robinson and Islam, 2015; 2011)

\subsection{Definition of Knowledge Translation}

Interesting enough, the types of knowledge translation are defined in several ways, according to the stakeholders and actors involved. Indeed, it can be seen as the translation:

- from science to clinical results (four results); meaning the translation of scientific research into clinical practices (like new medical protocols, pharmaceutical treatments, or surgical techniques);

- from the physician to the patient (one result), meaning the translation of clinical knowledge (e.g. diagnosis, potential treatments, risks, ...) from the healthcare professional to the sick person;

- from the patient to the physician (one result), meaning the translation of the feelings, priorities, goals, concerns from the ill person to his or her medical consultant;

- among scientists and professionals in the healthcare/clinical setting (three results), meaning the translation of scientific knowledge within professionals of different disciplines or backgrounds, which may include, as an example, various clinical specialities, engineering, biology, management, physics while dealing with a healthcare issue or research;

- from the central government to single units (one result), meaning the translation of healthcare policies, regulations, and guidelines;

- in general terms (eight results).

Only six articles clearly define the concept of "knowledge translation," some of them citing other works. Results are reported in the following table.

Table 3: Definition of Knowledge Translation

\begin{tabular}{|c|c|}
\hline Paper & KT definition \\
\hline $\begin{array}{l}\text { Dominant Cognitive Frames and the } \\
\text { Innovative Power of Social Networks } \\
\text { (D'Andreta et al., 2016) }\end{array}$ & $\begin{array}{l}\text { 'Knowledge Translation' is the process through which research findings } \\
\text { can be applied in medical practice (Denis and Lomas, 2003; McAneney et } \\
\text { al., 2010). }\end{array}$ \\
\hline $\begin{array}{l}\text { Strategies to promote practice nurse } \\
\text { capacity to deliver evidence-based care An } \\
\text { example from sexual healthcare } \\
\text { (Dadich, Abbott, and Hosseinzadeh, 2015) }\end{array}$ & $\begin{array}{l}\text { Knowledge translation is "any activity or process that facilitates the } \\
\text { transfer of high quality evidence from research into effective changes in } \\
\text { health policy, clinical practice, or products" (Lang, Wyer, and Haynes, } \\
2007, \text { p. 355). }\end{array}$ \\
\hline $\begin{array}{l}\text { Policy as a struggle for meaning: } \\
\text { disentangling knowledge translation } \\
\text { across international health contexts } \\
\text { (Komporozos-Athanasiou et al., 2011) }\end{array}$ & Translating evidence into practice \\
\hline $\begin{array}{l}\text { Assessing Knowledge Translation in } \\
\text { Iranian Medical Research Centres } \\
\text { (Mohaghegh et al., 2017) }\end{array}$ & $\begin{array}{l}\text { "Knowledge translation" is defined as turning knowledge into action } \\
\text { which includes "knowledge creation" and "knowledge application" to } \\
\text { improve taking advantage of research benefits (Graham et al., 2006) }\end{array}$ \\
\hline $\begin{array}{l}\text { Knowledge translation in healthcare } \\
\text { Incorporating theories of learning and } \\
\text { knowledge from the management } \\
\text { literature } \\
\text { (Oborn et al., 2013) }\end{array}$ & $\begin{array}{l}\text { The process of "knowledge translation" includes knowledge } \\
\text { dissemination, communication, technology transfer, ethical context, } \\
\text { knowledge management, knowledge utilisation, two-way exchange } \\
\text { process between researchers and those who apply knowledge, } \\
\text { implementation research, and development of consensus guidelines } \\
\text { (Canadian Institutes for Health Research - CIHR). } \\
\text { A few years later, the World Health Organization (2006) adapted the }\end{array}$ \\
\hline
\end{tabular}


CIHR's definition and defined knowledge translation as "the synthesis, exchange, and application of knowledge by relevant stakeholders to accelerate the benefits of global and local innovation in strengthening health systems and improving people's health."

Knowledge Sharing and Innovative Work Behaviour in Healthcare: A Micro-Level Investigation of Direct and Indirect Effects (Radaelli et al., 2014)
During idea promotion, individuals do not merely transmit information and data about the proposed innovation, but must also 'translate' these into a form that is understandable and palatable for other individuals and teams

\subsection{Knowledge translation tools}

The literature identifies 32 different knowledge translation tools and methods, which can foster or enhance the effective knowledge transfer and thus the creation of new knowledge and outcomes. Among the most frequent ones, we may mention online medical records ( 3 references), web portals (3 references), lesson learned and best practices ( 5 references), committee and meetings ( 3 references), mixed and interdisciplinary teams ( 5 references), training ( 6 references), interpersonal skills ( 5 references), and the use of testimonials ( 3 references). Full results are reported in the following table.

Table 4: Summary of Knowledge Translation tools

\begin{tabular}{|c|c|c|}
\hline Knowledge Translation Tool & Details & Sources \\
\hline $\begin{array}{l}\text { The pathogenesis and mechanisms behind } \\
\text { diseases }\end{array}$ & $\begin{array}{l}\text { The use of epidemiological observations to } \\
\text { understand the underlying causes of a disease }\end{array}$ & 1 \\
\hline $\begin{array}{l}\text { Mobile electronic Medical records and online } \\
\text { tools }\end{array}$ & The use of online or cloud-based apps or systems & 3 \\
\hline Design & $\begin{array}{l}\text { The use of design elements and artefacts like } \\
\text { sketches and images }\end{array}$ & 2 \\
\hline Web portals & The use of online web sites and other web tools & 3 \\
\hline Image tagging & The use of clinical imaging & 2 \\
\hline Lesson Learned and Best Practices & $\begin{array}{l}\text { The use or identification of past conducts which } \\
\text { proved to be successful or not, and that should or } \\
\text { should not be replicated }\end{array}$ & 5 \\
\hline Tours to share experiences with others & $\begin{array}{l}\text { Visiting in person other institutions, hospitals, or } \\
\text { organisations }\end{array}$ & 1 \\
\hline Committees and meetings & $\begin{array}{l}\text { The establishment of dedicated groups or group } \\
\text { gathering to discuss specific topics }\end{array}$ & 3 \\
\hline Journal publications & $\begin{array}{l}\text { Dissemination through publishing in academic or } \\
\text { non-scientific reviews, journals, magazines, } \\
\text { newspapers }\end{array}$ & 2 \\
\hline In-person visit and talking & $\begin{array}{l}\text { The use of face-to-face meetings with dedicated } \\
\text { time }\end{array}$ & 1 \\
\hline Establishment of mixed teams & $\begin{array}{l}\text { The creation of working teams made of diverse } \\
\text { people, including professionals with different } \\
\text { expertise, skills, and specialities }\end{array}$ & 5 \\
\hline Co-production & $\begin{array}{l}\text { The engagement of more meaningful } \\
\text { stakeholders, including patients, who take an } \\
\text { active part in the production of the healthcare } \\
\text { product or service }\end{array}$ & 2 \\
\hline Leaflets and brochures & $\begin{array}{l}\text { The use of printed or online booklets devoted to } \\
\text { one or more specific topics }\end{array}$ & 1 \\
\hline Training & The organisation of dedicated courses or classes & 6 \\
\hline Clinical cases & Explanations using past clinical case reports & 2 \\
\hline Clinical guidelines & $\begin{array}{l}\text { Explanations using guidelines issued by medical } \\
\text { scientific societies }\end{array}$ & 1 \\
\hline Use of interpersonal skills & $\begin{array}{l}\text { The use of soft skills like empathy, leadership, } \\
\text { teamwork }\end{array}$ & 5 \\
\hline Discussions, debates, curiosity & Time devoted to in-group talks & 1 \\
\hline New Technological tools & The use of modern technologies & 2 \\
\hline Mentoring and leadership & $\begin{array}{l}\text { Dedicated time to guide, teach, and assess other } \\
\text { people }\end{array}$ & 1 \\
\hline
\end{tabular}




\begin{tabular}{|c|c|c|}
\hline Knowledge Translation Tool & Details & Sources \\
\hline Testimonials & $\begin{array}{l}\text { The engagement of famous or reputable people, } \\
\text { whose knowledge or role is well recognised in } \\
\text { one specific field }\end{array}$ & 3 \\
\hline Engaging with the patient's family & $\begin{array}{l}\text { Including the patient's family members in the } \\
\text { discussion or decision-making process }\end{array}$ & 1 \\
\hline Empowerment & Giving more relevant roles to people & 2 \\
\hline Tensions & $\begin{array}{l}\text { Understanding eventual paradoxes to foster } \\
\text { decision-making }\end{array}$ & 1 \\
\hline Community of practice & $\begin{array}{l}\text { The use of a group of people to share knowledge } \\
\text { and learn }\end{array}$ & 1 \\
\hline $\begin{array}{l}\text { Multidisciplinary people (Eg. degree in medicine } \\
+ \text { IT) }\end{array}$ & $\begin{array}{l}\text { Getting people with more than one meaningful } \\
\text { skills or expertise within the team }\end{array}$ & 1 \\
\hline Use of evidence-based methods & $\begin{array}{l}\text { The use of methods which are backed up by } \\
\text { objective, scientific evidence that proves they are } \\
\text { effective }\end{array}$ & 2 \\
\hline Quality assessment by stakeholders & $\begin{array}{l}\text { Asking meaningful stakeholders to judge the } \\
\text { quality of one product, service, or process } \\
\text { according to certain standards or key } \\
\text { performance indicators }\end{array}$ & 2 \\
\hline Prototyping & $\begin{array}{l}\text { Using a first or preliminary version of a device } \\
\text { starting from its project, from which other forms } \\
\text { may be developed. }\end{array}$ & 2 \\
\hline Simulations & $\begin{array}{l}\text { Imitating a situation or process, to assess the } \\
\text { potential results or outcomes }\end{array}$ & 1 \\
\hline Self-assessment & $\begin{array}{l}\text { Self-evaluating the quality of one product, } \\
\text { service, or process according to certain standards } \\
\text { or key performance indicators }\end{array}$ & 2 \\
\hline Use of simple language & $\begin{array}{l}\text { Avoiding technical terms, and replacing them } \\
\text { with words from common language }\end{array}$ & 1 \\
\hline
\end{tabular}

\subsection{Findings, research implications, practical implications and policy implications}

Most papers explain the findings. Most interesting, while several articles stress how knowledge translation can be used in a practical way, just a few works highlight the eventual policy and research implications of the study.

\section{Discussion and implications}

This section aims to discuss the main findings to answer RQ3: What seem to be the possible implications for the research in this field of knowledge translation in healthcare and medicine? In trying to reply to this issue, we try to develop and address some emerging themes as outlined next.

\subsection{Implication 1: practitioners should be involved in the dialogue}

Scholars authored most papers, and there is limited involvement of practitioners in the dialogue. This evidence contributes to stress the academics and practitioners divide. While scholars typically use robust methodological approaches, practitioners use real knowledge translation tools in practice to achieve their own ends (Massaro et al., 2018). Given the practical aim of knowledge translation and its wide field of application in healthcare and medicine, stronger cooperation between academics and professionals should be recommended (Presch et al., 2020; Renaudin et al., 2018). Multidisciplinary research teams, merging scholars and practitioners with different skills and experience may be advised, as recommended by the most recent literature, especially following the COVID-19 experience (Albutt et al., 2020; Cobianchi et al., 2020c; Qadan et al., 2020).

\subsection{Implication 2: some areas of the world are more investigated than others}

Although our sample is limited, there are areas of the world which are over investigated, while others are absent or underinvestigated. Our literature review highlights the presence of several studies conducted in Australia, which may mean that the topic of knowledge translation is considered relevant in Australian institutions. The UK, continental Europe, and North America are investigated by some works. No studies have been conducted in Africa and Latin America, and only one article analyses Asia. This opens up to new research 
opportunities to investigate organisations in such locations and share eventual knowledge translation tools or best practices which may be useful also elsewhere in the world. Comparative studies may also be recommended, as only one paper investigates more countries together. Part of the literature analyses the topic of knowledge translation in general terms, without binding it to some specific location. This may mean that, in the Business and Management community, there is still interest towards a general discussion about knowledge translation as a theoretical topic, which dominant framework still needs to be clarified.

\subsection{Implication 3: the private sector deserves attention}

Our literature review highlights how almost all studies are about the public sector. This may be due to the availability or access to data by authors, most of whom are academics, as underlined in section 5.1. However, healthcare is a wide field that includes several institutions, firms, clinics, labs, and private universities that belong to the private sector. Understanding the knowledge translation processes in such organisations may open up to further research horizons. In a healthcare system which is becoming more and more interdisciplinary, blended situations are present, in which public and private healthcare institutions and companies cooperate. Understanding the knowledge translation dynamics may open up to further research avenues, and suggest new enablers and techniques which may be useful in practice. In such a perspective, the dialogue between academics and practitioners stand a key point in ensuring the more exciting results, which are linked to real-world situations.

\subsection{Implication 4: several healthcare services are investigated}

As reported in the previous sections, papers investigate several different healthcare services: from regenerative medicine to stroke, from pharma to palliative care. Only oncology and healthcare in general terms are analysed in more than one contribution. We may then highlight how much the topic of knowledge translation is transversal when it comes to healthcare and medicine, and the potential practical areas of investigation may be several.

\subsection{Implication 5: there is a lack of a dominant framework}

Section 4.7 has highlighted the absence of a dominant framework model, as no scheme is used in more than one paper. The fragmentation of the literature implies that there is the opportunity to study a common framework that may be used to compare studies and support managers and policymakers towards a useful integrated knowledge translation model. This idea is also supported by the relatively high number of general papers, which are not linked to a specific location, as reported in section 4.2.

\subsection{Implication 6: there is not a common definition of knowledge translation}

As for the framework model, there does not seem to be a unique definition of knowledge translation. Most articles even do not define it. Again, there is a research opportunity, to sum up previous descriptions to reach a standard paradigm, or, at least, to summarise the main points beyond the metaphorical language used (Bratianu and Bejinaru, 2019)

\subsection{Implication 7: there is an open list of knowledge translation tools}

Interestingly, even a limited sample of 18 publications led to 32 different knowledge translation tools and methodologies. Some of them seem more common, as they are mentioned in more works, some others are cited by only one article. As highlighted before, knowledge translation tools represent the engine to grant effective knowledge sharing, transfer, and the creation of new knowledge and outcomes. Identifying knowledge translation tools and how they can work in-action leads to practical implications, which may allow theory to be effective in the real world. There is indeed a need to collect more knowledge translation tools and methodologies and understand their dynamics in healthcare organisations, evaluating as they do work in action. Further studies investigating how some enablers and techniques work in practice may contribute to the theoretical debate, as well as to real-world implications.

\section{Conclusions}

In ending our work, we want to start from the premises of the study. We wanted to investigate the literature on knowledge translation, an increasing phenomenon which is particularly relevant in healthcare and medicine, where professionals and patients have different skills, competencies, and emotions, and thus find knowledge transfer difficult. The recent challenges that are questioning the way healthcare systems work have intensified the debate about the stakeholder's dialogue, and how different actors should be engaged and 
cooperate in the healthcare scenario. Given the growing interests towards the managerial and best practices to be applied in healthcare institutions to overcome the current challenges and address the main issues, we decided to concentrate first on the Business and Management literature, to see what the current debate was about. Our limited sample, grabbed from the works listed on Scopus and labelled under the Business and Management fields, highlights an increasing academic interest towards the topic. New research avenues can be defined, as a more significant involvement of practitioners and private institutions, the investigation of some locations and areas, the idea of establishing a standard framework and a set of definitions, and the collection of practical tools and techniques to ensure an effective sharing, transfer, and creation of knowledge. Particular emphasis is placed on the potential relevance of future studies that seek to revisit the concept of knowledge translation from a practitioner's perspective, to better understand not only the drivers of knowledge translation but also the methods used and their transferability across different contexts and domains.

As every study, this paper has several limitations. First, we focused only on peer-reviewed work listed on Scopus and labelled in the Business and Management fields. While including all studies in the clinical field may bias our research aim (thousands of papers, chapters and books only mention the translation factor, but are about clinical cases or techniques), a more comprehensive result may be gathered while enlarging the sample to medical journals devoted to public policies or the wide field of Social Sciences. Despite in academic research, the peer-review process is considered as a synonym for quality in published works, several other relevant publications can be missing, like articles or books in languages different than English. This means that while our findings are informative for the relevant research and practice communities, these may not necessarily be generalisable to every area within the healthcare sector or to every context, and some initiatives, frameworks and models focused on knowledge translation may have been inadvertently omitted. Moreover, the validity of results can only be granted at the time of the analysis, also considering the growing academic interest towards the topic of knowledge translation in healthcare. Future contributions may indeed change the validity of the outcome. Readers should recognise that SLRs are not a panacea offering ultimate answers. Instead, such literature review methodologies have the ambition to detect research gaps and further opportunities for future studies.

\section{References}

Albutt, K., Luckhurst, C.M., Alba, G.A., El Hechi, M., Mokhtari, A., Breen, K., Wing, J., Akeju, O., Kalva, S.P., Mullen, J.T., Lillemoe, K.T. and Kaafarani, H., 2020.Design and impact of a COVID-19 multidisciplinary bundled procedure team, Annals of Surgery, 272(2), pp e72-e73.

Ardito, L. and Messeni Petruzzelli, A., 2017. Breadth of external knowledge sourcing and product innovation: the moderating role of strategic human resource practices. European Management Journal, 35(2), pp. 261-272.

Aureli, S., Giampaoli, D., Ciambotti, M. and Bontis, N., 2019. Key factors that improve knowledge-intensive business processes which lead to competitive advantage, Business Process Management Journal, 25(1), pp. 126-143.

Avila-Robinson, A. and Islam, N. 2015. Evolution of emerging iPS cell-based therapies for age-related macular degeneration (AMD). In Portland International Conference on Management of Engineering and Technology, PICMET 2015 Portland, Oregon, USA, 2-6 August 2015, pp. 495-510.

Bagnoli, C., Dal Mas, F., Lombardi, R. and Nucciarelli, A., 2020. Translating knowledge through business model tensions. A case study. International Journal of Management and Decision Making, In Press.

Batalden, M., Batalden, P., Margolis, P., Seid, M., Armstrong, G., Opipari-arrigan, L. and Hartung, H., 2016. Coproduction of healthcare service. BMJ Quality \& Safety, 25(7), pp. 509-517.

Biancuzzi, H., Dal Mas, F., Miceli, L. and Bednarova, R., 2020. Post breast cancer coaching path: a co-production experience for women. In: P. Paoloni and R. Lombardi (Eds). 2020. Gender Studies, Entrepreneurship and Human Capital. IPAZIA 2019. Springer Proceedings in Business and Economics. Cham: Springer. pp. 11-23.

Bratianu, C. and Bejinaru, R., 2019. Knowledge dynamics: a thermodynamics approach. Kybernetes, 49(1), pp. 6-21.

Brindle, M. and Gawande, A., 2020. Managing COVID-19 in Surgical Systems. Annals of Surgery, 272(1), pp. e1-2.

Brunoro-Kadash, C. and Kadash, N., 2013. Time to care: A patient-centered quality improvement strategy. Leadership in Health Services, 26(3), pp. 220-231.

Cobianchi, L., Dal Mas, F., Peloso, A., Pugliese, L., Massaro, M., Bagnoli, C. and Angelos, P., 2020a. Planning the full recovery phase: an antifragile perspective on surgery after COVID-19. Annals of Surgery, In press, doi:10.1097/SLA.0000000000004489.

Cobianchi, L., Dal Mas, F., Piccolo, D., Peloso, A., Secundo, G., Massaro, M., Takeda, A., Garcia Vazquez, A., Verde, J.M., Swanstrom, L.L., Marescaux, J., Perretta, S., Gallix, B., Dimarcq, J.-L. and Gimenez, M.E. 2020b. Digital transformation in healthcare. The challenges of translating knowledge in a primary research, educational and clinical centre. In: K.S. Soliman (Ed.), International Business Information Management Conference (35th IBIMA), IBIMA, Seville, Spain, 1-2 April 2020, pp. 6877-6888. 
Cobianchi, L., Peloso, A., Vischioni, B., Panizza, D., Fiore, M.R., Fossati, P., Vitolo, V., lannalfi, A., Ciocca, M., Brugnatelli, S., Dominioni, T., Bugada, D., Maestri, M., Alessiani, M., Valvo, F., Orecchia, R. and Dionigi, P., 2016. Surgical spacer placement prior carbon ion radiotherapy ( CIRT): an effective feasible strategy to improve the treatment for sacral chordoma. World Journal of Surgical Oncology, 14(211), pp. 1-9.

Cobianchi, L., Pugliese, L., Peloso, A., Dal Mas, F. and Angelos, P., 2020c. To a new normal: surgery and COVID-19 during the transition phase. Annals of Surgery, 272, pp. e49-e51.

D’Andreta, D., Marabelli, M., Newell, S., Scarbrough, H. and Swan, J., 2016. Dominant cognitive frames and the innovative power of social networks. Organization Studies, 37(3), pp. 293-321.

Dadich, A., Abbott, P. and Hosseinzadeh, H., 2015. Strategies to promote practice nurse capacity to deliver evidence-based care: an example from sexual healthcare. Journal of Health, Organisation and Management, 29(7), pp. 988-1010.

Dadich, A. and Olson, R.E., 2017. How and why emotions matter in interprofessional healthcare. International Journal of Work Organisation and Emotion, 8(1), pp. 59-79.

Dal Mas, F., Biancuzzi, H., Massaro, M. and Miceli, L., 2020a. Adopting a knowledge translation approach in healthcare coproduction. A case study. Management Decision, In Press, doi:10.1108/MD-10-2019-1444.

Dal Mas, F., Massaro, M., Lombardi, R. and Garlatti, A., 2019a. From output to outcome measures in the public sector. A structured literature review. International Journal of Organizational Analysis, 27(5), pp. 1631-1656.

Dal Mas, F., Piccolo, D., Cobianchi, L., Edvinsson, L., Presch, G., Massaro, M., Skrap, M., Ferrario di Tor Vajana, A., D'Auria, S. and Bagnoli, C., 2019b. The effects of artificial intelligence, robotics, and industry 4.0 technologies. Insights from the Healthcare sector. In: Proceedings of the first European Conference on the impact of Artificial Intelligence and Robotics, Oxford, United Kingdom, 31 October -1 November 2019. Academic Conferences and Publishing International Limited, pp. 88-95.

Dal Mas, F., Piccolo, D., Edvinsson, L., Skrap, M. and D’Auria, S., 2020b. Strategy innovation, intellectual capital management and the future of healthcare. The case of Kiron by nucleode. In: F. Matos, V. Vairinhos, I. Salavisa, L. Edvinsson and M. Massaro, (Eds). 2020. Knowledge, People, and Digital Transformation: Approaches for a Sustainable Future. Cham: Springer. pp. 119-131.

Dal Mas, F., Piccolo, D. and Ruzza, D., 2020. Overcoming cognitive bias through intellectual capital management. The case of pediatric medicine. In: P.Ordonez de Pablos and L. Edvinsson (Eds) 2020. Intellectual Capital in the Digital Economy. London: Routledge. pp. 123-133.

Del Giudice, M. and Maggioni, V., 2014. Managerial practices and operative directions of knowledge management within inter-firm networks: a global view. Journal of Knowledge Management, 18(5), pp. 841-846.

Denis, J.L. and Lomas, J., 2003. Convergent evolution: the academic and policy roots of collaborative research. Journal of Health Services Research \& Policy, 8(2), pp. 1-6.

Elwyn, G., Nelson, E., Hager, A. and Price, A., 2020. Coproduction: when users define quality. BMJ Quality and Safety, 29, pp. 711-716.

Ferlie, E., Crilly, T., Jashapara, A., Trenholm, S., Peckham, A. and Currie, G., 2015. Knowledge mobilization in healthcare organizations: a view from the resource-based view of the firm. International Journal of Health Policy and Management, 4(3), pp. 127-130.

Garcia Vazquez, A., Verde, J.M., Dal Mas, F., Palermo, M., Cobianchi, L., Marescaux, J., Gallix, B., Dallemagne, B., Perretta, S. and Gimenez, M.E., 2020. Image-guided surgical e-learning in the post-COVID-19 pandemic era: what is next? Journal of Laparoendoscopic \& Advanced Surgical Techniques, In Press. doi.org/10.1089/lap.2020.0535

Giulianotti, P.C., Coratti, A., Angelini, M., Sbrana, F., Cecconi, S., Balestracci, T. and Caravaglios, G., 2003. Robotics in general surgery: personal experience in a large community hospital. Archives of Surgery, 138(7), pp. 777-784.

Graham, I.D., Logan, J., Harrison, M.B., Straus, S.E., Tetroe, J., Caswell, W. and Robinson, N., 2006. Lost in knowledge translation: time for a map?. Journal of Continuing Education in the Health Professions, 26(1), pp. 13-24.

Grasselli, G., Pesenti, A. and Cecconi, M., 2020. Critical care utilization for the COVID-19 outbreak in Lombardy, Italy, JAMA, 323(16), pp. 1545-1546.

Groenier, M., Pieters, J.M. and Miedema, H.A.T., 2017. Technical medicine: designing medical technological solutions for improved health care. Medical Science Educator, 27(4), pp. 621-631.

Hogan, A.R., Doni, M., Damaris Molano, R., Ribeiro, M.M., Szeto, A., Cobianchi, L., Zahr-Akrawi, E., Molina, J., Fornoni, A., Mendez, A.J., Ricordi, C., Pastori, R.L. and Pileggi, A., 2012. Beneficial effects of ischemic preconditioning on pancreas cold preservation. Cell Transplantation, 21(7), pp. 1349-1360.

Howdon, D. and Rice, N., 2018. Health care expenditures, age, proximity to death and morbidity: Implications for an ageing population. Journal of Health Economics, 57, pp. 60-74.

Hussain, S. and Sanders, E.B.N., 2012. Fusion of horizons: Co-designing with Cambodian children who have prosthetic legs, using generative design tools. CoDesign, 8(1), pp. 43-79.

Jacquinet, M., Curado, H., Nobre, A.L., Sousa, M.J., Arraya, M., Pimenta, R. and Martins, A.E., 2019. Management of tacit knowledge and the issue of empowerment of patients and stakeholders in the health care sector. In: Information Resources Management Association. 2019. Healthcare policy and reform: concepts, methodologies, tools and applications, Hershey: IGI Global.

Komporozos-Athanasiou, A., Oborn, E., Barrett, M. and Chan, Y.E., 2011. Policy as a struggle for meaning: disentangling knowledge translation across international health contexts. Knowledge Management Research and Practice, 9(3), pp. 215-227. 
Lakoff, G. and Johnson, M. 1999. Philosophy in the flesh. The embodied mind and its challenges to western thought. New York: Basic Books.

Lander, B., 2016. Boundary-spanning in academic healthcare organisations. Research Policy, 45, pp. 1524-1533.

Lang, E.S., Wyer, P.C. and Haynes, R.B., 2007. Knowledge translation: closing the evidence-to-practice gap. Annals of Emergency Medicine, 49, pp. 355-363.

Lillemoe, K.D., 2020. COVID-19 moving forward, [online] Available at: https://journals.Iww.com/annalsofsurgery/Pages/COVID-19.aspx [Accessed 17 August 2020].

Massaro, M., Dumay, J. and Garlatti, A., 2015. Public sector knowledge management: a structured literature review. Journal of Knowledge Management, 19(3), pp. 530-558.

Massaro, M., Dumay, J., Garlatti, A. and Dal Mas, F., 2018. Practitioners' views on intellectual capital and sustainability: from a performance-based to a worth-based perspective. Journal of Intellectual Capital, 19(2), pp. 367-386.

Massaro, M., Dumay, J.C. and Guthrie, J., 2016. On the shoulders of giants: undertaking a structured literature review in accounting. Accounting, Auditing and Accountability Journal, 29(5), pp. 767-901.

Massaro, M., Handley, K., Bagnoli, C. and Dumay, J., 2016. Knowledge Management in small and medium enterprises. A structured literature review. Journal of Knowledge Management, 20(2), pp. 258-291.

Massaro, M., Moro, A., Aschauer, E. and Fink, M., 2019. Trust, control and knowledge transfer in small business networks. Review of Managerial Science, 13(2), pp. 267-301.

McAneney, H., McCann, J., Prior, L., Wilde, J. and Kee, F., 2010. Translating evidence into practice: a shared priority in public health? Social Science \& Medicine, 70, pp. 1492-1500.

Miceli, L., Bednarova, R., Di Cesare, M., Santori, E., Spizzichino, M., Di Minco, L., Botti, R., Casciello, M. and Della Rocca, G., 2017. Outpatient therapeutic chronic opioid consumption in Italy: a one-year survey. Minerva Anestesiologica, 83(1), pp. 33-40.

Miller, L.M., 2015. E-health: knowledge generation, value intangibles, and intellectual capital. International Journal of Healthcare Management, 8(2), pp. 100-111.

Mohaghegh, N., Zarghani, M., Tahamtan, I., Ghasghaee, A. and Mousavi, S., 2017. Assessing knowledge translation in Iranian medical research centres. International Journal of Information Science and Management, 15(2), pp. 145-156.

Morlacchi, P. and Nelson, R.R., 2011. How medical practice evolves: learning to treat failing hearts with an implantable device. Research Policy, 40, pp. 511-525.

Nelson, R.R., Buterbaugh, K., Perl, M. and Gelijns, A., 2011. How medical know-how progresses. Research Policy, 40, pp. 1339-1344.

Oborn, E., Barrett, M. and Racko, G., 2013. Knowledge translation in healthcare: incorporating theories of learning and knowledge from the management literature. Journal of Health Organization and Management, 27(4), pp. 412-431.

Parodi, S.M. and Liu, V.X., 2020. From containment to mitigation of COVID-19 in the US. Jama, 323(15), pp. 1441-1442.

Pinker, S., 2007. The stuff of thought. Language as a window into human nature, New York: Penguin Books.

Presch, G., Dal Mas, F., Piccolo, D., Sinik, M. and Cobianchi, L., 2020. The World Health Innovation Summit (WHIS) platform for sustainable development; from the digital economy to knowledge in the healthcare sector. In: P. Ordonez de Pablos and L. Edvinsson (Eds) 2020. Intellectual Capital in the Digital Economy. London: Routledge. pp. 19-28.

Qadan, M., Hong, T.S., Tanabe, K.K., Ryan, D.P. and Lillemoe, K.D., 2020. A multidisciplinary team approach for triage of elective cancer surgery at the Massachusetts General Hospital during the novel Coronavirus COVID-19 outbreak. Annals of Surgery, 272(1), e20-e21.

Radaelli, G., Lettieri, E., Mura, M. and Spiller, N., 2014. Knowledge sharing and innovative work behaviour in healthcare: a micro-level investigation of direct and indirect effects. Creativity and Innovation Management, 23(4), pp. 400-414.

Reay, S., Collier, G., Kennedy-Good, J., Old, A., Douglas, R. and Bill, A., 2017. Designing the future of healthcare together: prototyping a hospital co-design space. CoDesign, 13(4), pp. 227-244.

Renaudin, M., Dal Mas, F., Garlatti, A. and Massaro, M., 2018. Knowledge Management and cultural change in a knowledge-intensive public organization. In: D. Remenyi (Ed 2018. 4th Knowledge Management and Intellectual Capital Excellence Awards, Reading: Academic Conferences and Publishing International Limited. pp. 85-96.

Saini, K.S., Taylor, C., Ramirez, A.J., Palmieri, C., Gunnarsson, U., Schmoll, H.J., Dolci, S.M., Ghenne, C., Metzger-Filho, O., Skrzypski, M., Paesmans, M., Ameye, L., Piccart-Gebhart, M. J. and de Azambuja, E., 2012. Role of the multidisciplinary team in breast cancer management: results from a large international survey involving 39 countries. Annals of Oncology, 23(4), pp. 853-859.

Sánchez-Polo, M.T., Cegarra-Navarro, J.-G., Cillo, V. and Wensley, A., 2019. Overcoming knowledge barriers to health care through continuous learning. Journal of Knowledge Management, 23(3), pp. 508-526.

Savory, C., 2006. Translating knowledge to build technological competence. Management Decision, 44(8), pp. 1052-1075.

Savory, C., 2009. Building knowledge translation capability into public-sector innovation processes. Technology Analysis \& Strategic Management, 21(2), pp. 149-171.

Secundo, G., Toma, A., Schiuma, G. and Passiante, G., 2019. Knowledge transfer in open innovation: a classification framework for healthcare ecosystems. Business Process Management Journal, 25(1), pp. 144-163.

Simeone, L., Secundo, G. and Schiuma, G., 2017. Adopting a design approach to translate needs and interests of stakeholders in academic entrepreneurship : the MIT Senseable City Lab case. Technovation, 64-65(July), pp. 58-67.

Simeone, L., Secundo, G. and Schiuma, G., 2018. Arts and design as translational mechanisms for academic entrepreneurship : the metaLAB at Harvard case study. Journal of Business Research, 85, pp. 434-443. 
Sousa, M.J., 2010. Dynamic knowledge: an Action Research Project. The International Journal of Knowledge, Culture and Change Management, 10(1), pp. 317-331.

Sousa, M.J., 2015. Innovation: the key for creating and sharing knowledge. In G. Jamil (Ed.) 2015 Effective project management through the integration of knowledge and innovation, Hershey: IGI Global.

Sousa, M.J., Dal Mas, F., Garcia-Perez, A. and Cobianchi, L, 2020. Knowledge in transition in healthcare. European Journal of Investigation in Health, Psychology and Education, 10(3), pp. 733-748.

Vitolo, V., Cobianchi, L., Brugnatelli, S., Barcellini, A., Peloso, A., Facoetti, A., Vanoli, A., Delfanti, S., Preda, L., Molinelli, S., Klersy, C., Fossati, P., Orecchia, R. and Valvo, F., 2019b. Preoperative chemotherapy and carbon ions therapy for treatment of resectable and borderline resectable pancreatic adenocarcinoma: a prospective, phase II , multicentre , single-arm study. BMC Cancer, 19(922), pp. 1-7.

Wang, C.J., Ng, C.Y. and Brook, R.H., 2020. Response to COVID-19 in Taiwan: big data analytics, new technology, and proactive testing. JAMA, 323(14), pp. 1341-1342.

Ware, C., Buckwell, C., Small, S. and Wood, R., 2008. Activation of evidence: a new approach to knowledge translation and closing the clinical care gap. Journal of Medical Marketing, 8(2), pp. 127-136.

WHO. 2020. Coronavirus disease (COVID-19) pandemic, health topics, [online] Available at: https://www.who.int/emergencies/diseases/novel-coronavirus-2019 [Accessed 17 August 2020]. 